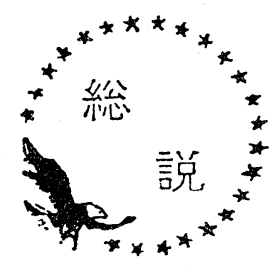

1.はじめに

1969年11月 4 日，はるか 6 千キロも離れた，アラス カより，3万トンの L NG(液化天然ガス)を積んだ， LNGタンカー「ポーラー・アラスカ号」が，はじめ て, 横浜市磯子地区にある, 東京ガス根岸工場に到着 し, 荷揚げしたことは, 読者のご記憶に新しいことで あるら。

このL N G は天然ガスを低温で泠却, 液化したもの で, 大量に取扱われる場合は, 常圧で $-160^{\circ} \mathrm{C}$ 程度の 条件が普通である。このようにすると, 常温のガス状 に比較して, その容積は, 約 600 分 1 の縮少するので 輸送, 貯蔵が経済的になり, これによつて, 天然ガス の海上輸送が可能になつたともいえる。もちろんこの 場合, $-160^{\circ} \mathrm{C}$ といら低温で L N Gを運搬するタンカ 一の開発を見逃すことはできない。

この L N Gの海上輸送が，商業的規模で始まつたの は，1964年，アルジェリヤのアルズウから，1万2,000 トンのタンカー「メタンプリンセス号」「メタンプロ グレス号」がイギリスのキャンベイに，ついで翌 年, 同じ所から1万 1,000 トンの「ジュールベルン号」 がフランスのルアーブルヘ, 定期的に輸送した時であ つた。そして当時の $L N G$ 導入の背景は, 資源に貧し い国が，放置されていた新しいエネルギーに着眼し， 石炭や石油と競合しらるもの, あるいはそれらの資源 の量堂補助するものであるといら考えにたち, 都市ガ ス用としてであつたが, その後, 導入を開始したわが 国における背景は, これに加えて公害のない貴重な工 ネルギーとしてLNGに注目し，火力発電用燃料とし て使用したことにある。

このようにして, 現在では, 天然ガスや LNGは欧 米や日本で大量に使用されるようとしている。そこ で, ここでは, 新しいエネルギーとして L N Gが総エ ネルギーにしめる位置, さらに新しい用途などを述べ L NGの今後の役割についてふれてみたい。

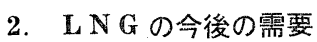

科学技術庁の資科によると表 1 亿女るように，1968 年 6 月の, 世界の天然ガス埋蔵量は, 37 兆 6,260 億 $\mathrm{m}^{3}$ といわれ，生産量は， 8,355 億 $\mathrm{m}^{3}$ に達している。
東京瓦斯株式会社 野 尻正信

この数字は, エネルギー量としてみると，それぞれ 原油の規模のちようど 2 分の 1 亿拉よんでいるが，そ の伸び率は, 原油よりさらに高く, 全エネルギ一消費 中に占める天然ガスの割合は，1955年，12.3\%，1964 年，17.6\%，1980年， $20 \%$ ，さらに1985年，すなわち 今から, 約 15 年先には, $25 \%$ にもなると予測されて いる。しかも, これらの割合は, 天然ガスが単に資源 としての考えにたつているもののみで, 他のエネルギ 一と比較して, イオウ分を含まないなどの優れた特性 から, 都市公害, 産業公害の防止対策上, 最適のエネ ルギーであるといらことを考光合わせれば，さらに大 きくなる可能性がある。このよらに考えていくと, 天 然ガスは, エネルギーとして, 今後ますます重要な位 置をしめていくと思われるが，表1を見てわかるよう に, 各国別の埋蔵量と消費量の間, あるいは生産国と 消費国の間には, 大きな不均衡がある。しかし, 開発 途上国や，自国消費量を，さらにうわまわる生産国一 カナダ, ソ連一の天然ガスは, パイプラインや, L N Gとして, 陸上や海上から, 今後大いに活発に輸送さ れ，そして消費されるだろう。

わが国の場合，1985年（昭和60年）のエネルギー総 消費量は, 一説に上れば粗鋼生産年間 1 億 6,000 万 $\mathrm{t}$, 経済成是率 $6 \%$ として, 石油換算で年間 8 億 $\mathrm{k} l$ とい5 予測もされている。このぼら大な量のエネルギー消費 については, 今後の経済成長率の見直しなどによつ て，若干少なくなるだろらが，いずれにしても，これ を確保するには, 昨年末の資源調查会の中間報告でも 供給国の多様化, 自国産の開発などに加えて, 天然ガ スの利用を積極的に進めるべきだと指摘している。こ のようにエネルギーの多様化が進みさらに対公害エネ ルギーとして注目をあびている天然ガスの消費量は, 推定することが非常に困難であるが，欧米の事情から 類推して, 総エネルギー消費量の約 $20 \%$ として, 約 1 , 000 億 $\mathrm{n}^{3}$ にもなる。これは現在の国内需要（昭和44年 度，24億 3,000 万 $\left.\mathrm{m}^{3}\right)$ の約 40 倍にもなる。通産省鉱山 石炭局が予測したところによると, 昭和60年度までに は国内天然ガスの開発を進め, その生産量は, 年間13 0億 $\mathrm{m}^{3}$ にするといっている。したがつてその残りの 8 
表 1 世界の国別天然ガス統計

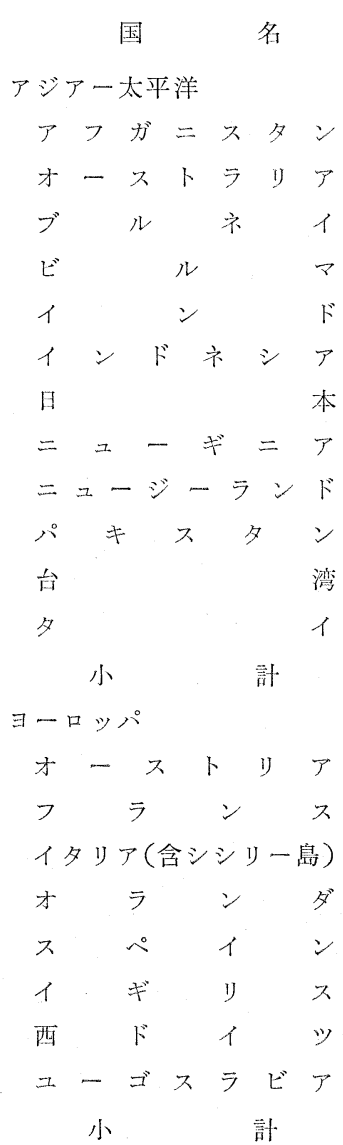

中東

ア プ ダ ビ

バーライイン

デーバー イ

イラン

15 ク

イスラエル

ク ウェ - 卜

マスカットオーマン

中立地带

力 夕 多 ル

サウジアラビア

シ リ ア

トルコ

小 郭

アフリカ

アルジェリア

アンゴラ(含カビンダ)

\begin{tabular}{|c|c|c|}
\hline $\begin{array}{c}\text { 埋蔵量 } \\
1968 \text { 年 } 6 \text { 月 } 1 \text { 日 } \\
10^{9} \mathrm{~m}^{3}\end{array}$ & $\begin{array}{c}\text { 生産量 }(\mathrm{P}) \\
1967 \text { 年 } \\
10^{6} \mathrm{~m}^{3}\end{array}$ & $\mathrm{R} / \mathrm{P}$ \\
\hline 142 & - & \\
\hline 453 & 43 & 10,500 \\
\hline 14 & - & \\
\hline 3 & - & \\
\hline 28 & $1,221.4$ & 23 \\
\hline 69 & $3,351.0$ & 21 \\
\hline 6 & $1,890.0$ & 3 \\
\hline - & - & \\
\hline 13 & 0.1 & 130,000 \\
\hline 575 & $2,368.0$ & 243 \\
\hline 27 & 527.2 & 51 \\
\hline- & - & \\
\hline 1,330 & $9,362.0$ & \\
\hline 23 & $1,797.0$ & $1:$ \\
\hline 227 & 5,563 & 41 \\
\hline 185 & 9,367 & 20 \\
\hline 2,354 & 7,156 & 329 \\
\hline - & - & \\
\hline 864 & 476 & 1,815 \\
\hline 290 & 3,273 & 89 \\
\hline 99 & 465 & 213 \\
\hline 4,042 & 28,097 & \\
\hline
\end{tabular}

23

3

243

51

$1:$

20

329

815

213

2,124

28

$3 \quad 109$

1,133

20

99

212

2,303

92

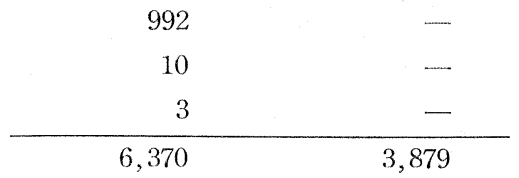

3,966

$2,1580.0$

1,338

14

2.7

5,185 


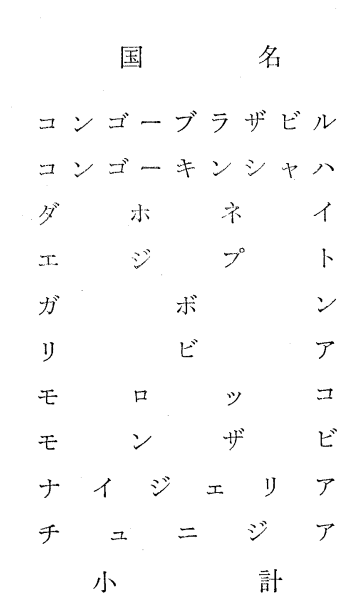

南

南米

アルぜンチン

バルトドス

ボリビリ

ブ ラ ジ ル

チ リ

コロレビ

エクアドル

小ンジュラス

メキシコ

ヘN -

トリニダードトバゴ

ベネズエラ

小 計

$\begin{array}{llll}\text { 北 } & \text { 米 } & \\ \text { 力 } & \text { ナ } & & \text { ダ } \\ \text { ア メ リ カ 合 衆 国 }\end{array}$ 小 計

$\frac{\text { 自由諸国合計 }}{\text { 東ヨーロッパ, ソ連拄よ゙中 }}$

アルバ $ル ア$

ブルガリア

中 国

チェコスロバキア

東ドイッ

八ンガリ

ポー ランド

ルーマーマー

y 逋

\begin{tabular}{ccc} 
小 & 計 \\
\hline 総 & 合
\end{tabular}

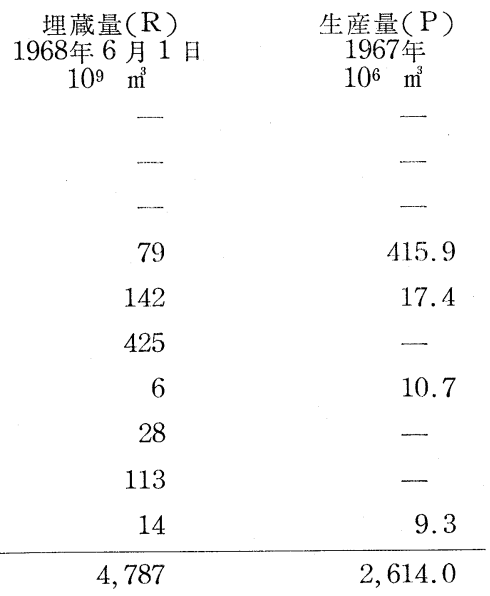

201

$3,916.0$

862.7

875.0

1.7

2.8

0.2

-

368

$16,367.0$

22

57

34

768.0

44

\begin{tabular}{rr}
907 & $25,920.6$ \\
\hline 1,948 & $48,714.0$
\end{tabular}

1,295

48,100

28

8, 299

511,456

16 559,556

$\frac{9,594}{28,071}-\frac{559,556}{652,222}$

(Internatioal Petroleum Enc yclopedia 1969) 


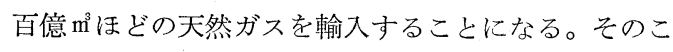
ろになれば, ソ連からの天然スガの導入も具体化し, 一部はパイプラインでわが国に入つてくることも考え られるが，その他は輸入 L N Gで，この量忤閒数千 万七 になる可能性もある。

\section{L N G 導入の経済規模}

前述したように, 今後L NGの需要はますます増大 することは予測されるが，その導入には種々な条件が 付加されてくる。天然ガスをパイプラインで消費地へ 送るより, 液化・海上輸送・再ガス化の方がガスの価 格が高くなるのはもちろんである。これを補らために は, 液化, 輸送, 受入再ガス化の設備費をコストダウ ンするために，技術改良をしていくことと，さらに導
入規模を大きくして，そのスゲール効果をあげること がある。

すでに実施されているアルジェリヤとイギリス，フ ランス間のプロジェクトや，アラスカと日本の間のプ ロジェクトで, 年閒導入量が約 100 万 $\mathrm{t}$ の規模であっ たように，最小経済規模は100万坛といわれていた。 しかし, 昨今のタンカー建造費の上昇や, 現地液化設 備や受入設備にかかる資材費や人件費の高騰に伴つ て, 現在では, その導入規模は, 表 2 にられるよう に, リビヤとイタリヤ，スペイン間の計画の年間 300 万 $\mathrm{t}$, ブルネイと日本間の 400 万 $\mathrm{t}$, あるいは, アル ジェリヤとアメリカ間の 800 万 $\mathrm{t}$ と, 徐々に大型化し, 経済規模の単位は 400 万 $\mathrm{t}$ から 500 万 $\mathrm{t}$ 程度になつて

\section{表 2 L N G 海上輸送状況および計画}

$$
\begin{aligned}
& \text { 出荷地 }
\end{aligned}
$$

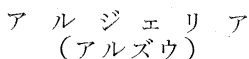

$$
\begin{aligned}
& \text { アルジェリア } \\
& \text { （アルズウ） } \\
& \text { ア (こキスキ } \\
& \text { リ (ブレ゙ガ })^{\text {ア }} \\
& \text { リ }\left(\begin{array}{l}
\text { ビ } \\
\text { ガ }
\end{array}\right. \\
& \text { アルジェリア } \\
& \text { ブ ル ネ采 イ } \\
& \text { ア } \underset{(\text { ダマ息 })}{ } \\
& \text { アルジェリア } \\
& \text { (アルズウ) } \\
& \text { ベネズエラ } \\
& \text { (レ゙ーク・ズェラカ } \\
& \text { アルジェリア } \\
& \text { アルジェリア }
\end{aligned}
$$$$
\text { 受大地 }
$$

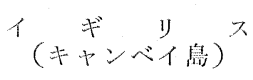$$
\text { ᄀ }{ }_{(\text {ルアーブル) }}
$$$$
\text { 日 根 }
$$$$
\text { 岸) }
$$$$
\text { 个(ラスペチア })^{ア}
$$$$
\text { ス } \underset{\text { ペルセロロナ })}{ }
$$

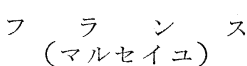$$
\text { （根岸・袖ケ浦・泉北） }
$$$$
\text { 日 }
$$$$
\text { 本 }
$$$$
\text { アメリカ東海岸 }
$$$$
\text { アメリカ東海岸 }
$$$$
\text { アメリカ東海岸 }
$$$$
\text { アメリカ東海岸 }
$$$$
\text { アメリカ東海岸 }
$$

（東京瓦斯調查1970-10）

いる。

このように大型化してくると, わが国の場合, これ を単一企業で消化することは不可能である。現実に は, 100 万 $\mathrm{t}$ の規模でさえ, 東京ガスは東京電力と協 同購入といら形式をとつているし，また現在計画中の ブルネイからの導入も東京ガス, 東京電力, 大阪ガス との 3 社其同購入といら形式をとつている。このよら に電力とガスといら, 共同購入方式の外ならず, 導入
出荷開始

1964年10月

1965年 3 月

1969年11月

1970年予定

(タンカー冷凍設備は完了

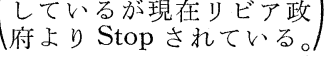

1971年〜

1972年訫

1972年末

1973年計画

1973年

1974年計画

1975年計画

1975年計阳

1975年計画

末 定

のスケール效果を高めるため, またエネルギーとして その役割をはたすためには,さらに使用分野の開発を 進め, それ以外の複数企業体による共同大量導入をし なくてはならないと考える。そこでつぎに, L NGの 新用途の何能性について述べてみよう。

\section{L N Gの 新用 途}

4-1 サテライト基地用燃料

LNGの可搬性の良さについて前述したが，この特 
性は陸上の運搬にもいえる。都市ガスの供給網から隔 離した地域や小都市で小規模導管網のあるところへ, ローリーなどで輸送し, 再ガス化使用することもでき る。この用途については, 現在の L P G とも競合す ることになるが，都市ガスとしては天然ガスの方が比 重が軽く, 室内に停滞しにくいこと, 爆発下限界も高 いことなど, 安全性の点で優れており, とくに将来都 市ガス導管網に連結しうるような地点では, 需要がガ ス導管の経済規模に達するまで, 暫定的に L N G を供 給することが十分成立しうると思われる。この場合, 再ガス化の気化熱を食品冷谏などに利用することによ り，さらに効果があがる。

\section{$4-2$ 自動車用燃料}

天然ガスを自動車用燃料として使用することは，古 くは, 第一次世界大戦以後イタリヤで始められた。わ が国でも, 天然ガスの産出する新潟県や千葉県では, 早くから行なわれていたが，いずれの場合も圧縮ガス を使用していたことと，そのガス補充所の場所が限定 されていることなどで, 地域的にしか発達しなかつ た。しかし昨今, アメリカでは公㲅防止の見地から， 天然ガスが改めて見直されるようになつた。元来天然 ガス然料としては実績があつたものの圧縮ガスを積ん でいくためには, 何本ものボン心゙を積まなくてはなら

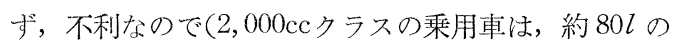
ガソリンが積めるが，これと等価熱量の圧縮天然ガス ボン心゙は25本も必要である)，L N G を利用する車の 開発が，南カリフォルニヤのロスアンゼルスを中心に 進めら机ている。そして現在では, デュアルフュエル 式の気化器が開発され, この地方にはガソリンと L N Gの両方を使用できる乘用車が数干台㐫るといわれて いる。しかしこれが本格的になるには, まだいくつか の技術的あるい滴業的な開発が必要で, とくに安価 な燃料タンクの製造に問題がある。 $-160^{\circ} \mathrm{C}$ の L G を入れるので内殼はステンレス鋼, 外殼は普通鋼で作 つた。二重殼構造とし, その中にパーライトを入れ真 空断熱にした保冷容器であるがこれが量産に対するネ ックになつているといわれている。

しかし, サンディエゴガス・電気会社の L N G 車の 実験では, カリフォルニヤ州の乗用車排気基準の炭化

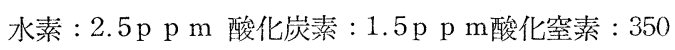
p p mを下まわることが判明した。また光化学スモッ グの原因になる排気中のパラフィン族, オレフィン 族, 芳香族の合計であらわす活性指数は, ガソリン車 の 6 分の 1 亿すぎず，これらの諸点を合わせて，大気 污染防止上から，L N G はかなり有効なものとなりそ
らである。さらにエンジンは, タールやスラッジなど の生成も少ないので，污れによる損粍やスラッジなど の生成も少ないので, 污れによる損粍が少なく, 保守 経費に取ぼす效果も見のがせない特徽といえよう。

\section{$4-3$ 航空機用燃料之冷媒}

航空機の燃料は, 約70年前, ライト兄弟が初めて空 を飛んで以来, 灯油, ガソリン, J Pなどに変わつて 来たが，いずれももつとも古い灯油の類似品と見なし てもよい。しかし，プロペラからターボプロップ，ジ エット機, あるいはジャンボ機, 超音速機 (S S T) と変わるにつれ, 空気力学, 機体構造, 推進機の技術 は成功をおさめたが，航続距離をのばし，速度をはや め，乗客数を增加するなどをそなえた経済的に成立す る新しい航空機を開発するには, 新しい燃料が必要で この用途として，1964年，アメリカ航空宇宙局（NA SA）で最初にLNGが注目された。

これらの航空機燃料として, LNGがとくに適して いるのは, 大型のS STである。その最大の理由は L NGのもつヒートシンク，すなわち $-160^{\circ} \mathrm{C}$ から 650 ${ }^{\circ} \mathrm{C}$ 位まで広範囲な温度にわたつてクラッキングするこ とがないので，色々な冷媒として利用できることと， 単位重量当たりの発熱量が大きいことにある。このう ち前者のヒートシンクについては, タービンエンジン の羽根の冷却源に L N G を利用することによつて羽根 の金属温度を下げることができるので，タービン入口 の燃料ガスの温度を上げることができ, タービンの出 力を増加することができる。NASAの論文によれば マッハ 3 で重量 $219 \mathrm{t}$ のS S T の場合 J P を使つて夕 ービン人口温度が $1,200^{\circ} \mathrm{C}$ とき, 210 人の乗客が運べ るものが，L N Gを使つて温度が $1,500^{\circ} \mathrm{C}$ ときは 255 人になる。これは20\%増しの乗客が乗れることにな り，その効果は大きい。さらにエアーコンディショニ ングやギヤボックス, 電子装置, 油圧装置など, 泠却 用にも使用でき, 今までエンジン出力のエネルギーの 一部をこれらの冷凍機用の動力に使つていたことから すれば，全体の燃料費は少なくてすみ，それでもエン ジン出力は大きくなる。

この他都市ガスの項で述べたような安全性でも優 れ, また L N G は非常に清浄な燃料であるので, 燃料 系統の閉そく, タービン羽根の腐食や侵食, 硫化とい つた問題もなくなる。

このように理想的な L NG燃料にも久点がある。そ の第 1 は, 比重量が小さいので大きな燃料タンクが必 要なことで，それは重量を重くする要素にもなり，ま た空気抵抗を増すことにもなる。しかし自動車と同じ 
ように燃料タンクの断熱方法, エンジンの開発などを 含めて, NASAやプラットアンドホイットニイ社な どで実用化のための努力が続けられている。

また L NGをへリコプターに使ら場合も，これらの 利点はそのまま生かせられるので, 高出力の小型エン ジンが可能である。またへリコプターは騒音が一つの ネックであるが，LNGでは単位出力当たりの排気量 が減少するので, 大型エンジンでも騒音は従来のもの より少なくなり，これはへリコプターの新しい都市高 速交通機関としての発達には大いに寄与することにな 万う。

\section{$4-4$ 鉄鋼用然料}

科学技術庁資源調查会の調查によると, 粗鋼 1000 万 $\mathrm{t}$ の製鉄所で，重油使用量だけをLNGに換算すると年 間約 100 万 $\mathrm{t}$ の量になる。近年, 鉄鋼流通機構の合理 化，るるい消費地一の運搬費の節約から，むしろ都 市工業地带に非常に近く製鉄所が建てられる傾向があ り，これらの状沉を考えると，公害詨策上から都市ガ ス, 電力についで, 早いピッチで $\mathrm{L} N \mathrm{NG}$ 導入が具体 化するのではないかと思われる。

鉄鋼業でLNGを燃料として使用できる分野は，高 炉吹込み，平炉，熱処理炉，鋳型乾燥炉，雾囲気炉，
鋼材切断用などである。

高炉吹込用熱源として，主燃料はコークスであるが 近年は重油やコークス炉ガスを高炉羽口から吹込儿 で，できるだけコークス量を減少させ，出銑量を增大 させる法がとられている。アメリカやソ連では，天然 ガスの吹込み走行なつており，銑鉄 $1 \mathrm{t}$ 当たり 40〜80 m しているといわれている。この他の利点としては, 羽 口先で天然ガスが水素と一酸化炭素に分解し，これが 還元前として溶鈗に作用し生産によい，コークスの灰 分による鈗滓生成が減少し，さらに熱收支がよい，天 然ガスはイオウ分を含まないので, 製品の品質を向上 させるなどの点がある。

この他L NGの新しい用途として直接還元製鉄法が ある。これは鉄鉣石を高炉を使わずに流体還元剤によ つて還元製鉄する新しい技術で，鉄鉣石を粉末にし て，天然ガスを改質してえられた水素と一酸化炭素か らなる還元用ガスで還元させて，成分的には銑鉄と鋼 との中閐的な粉鉄または海綿鉄を作る方法である。表 3 のよらに外国では各社がテストプラントを建設して いるが，わが国の場合はL N Gの価格が相当安くなる ことが決め手になる。

\section{表 3 天然ガス利用の直接製鉄法}

\begin{tabular}{|c|c|c|c|c|}
\hline 会 社 名 & 場 & 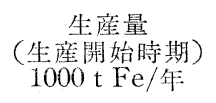 & 製鉄方式 & $\begin{array}{l}\text { 天然ガス使用 } \\
\text { 原笛位 } \\
\mathrm{N} \mathrm{m} \text { 成品 }\end{array}$ \\
\hline \multirow{2}{*}{ アランウッド } & $\begin{array}{c}\text { モキテレイ } \\
(\text { メキシコ) }\end{array}$ & $\begin{array}{c}70 \\
(1957)\end{array}$ & HYL & \multirow{2}{*}{ 約 600 前後 } \\
\hline & $\begin{array}{c}\text { ベエクルッ } \\
(\text { (メキシコ) }\end{array}$ & $\begin{array}{c}175 \\
(1967)\end{array}$ & $\begin{array}{l}\text { (レトルト } \\
\text { 還元器方式) }\end{array}$ & \\
\hline I $\%$ y & $\begin{array}{c}\text { メシコ沙沿岸 } \\
\text { (アメリカ) }\end{array}$ & $\begin{array}{c}500 \\
(1972)\end{array}$ & $\begin{array}{l}\text { E S S O-Fior } \\
\text { (流動床方式) }\end{array}$ & 600 前後 \\
\hline 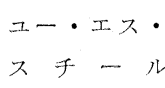 & $\begin{array}{c}\text { オ, I } \\
\text { (ベネズエラ }\end{array}$ & $\begin{array}{c}1000 \\
(1970)\end{array}$ & $\begin{array}{l}\text { NU-Irom } \\
\text { （流動床方式） }\end{array}$ & 700 前後 \\
\hline ギルモア & $\begin{array}{c}\text { ポートランド } \\
\text { (アメリカ) }\end{array}$ & $\begin{array}{c}400 \\
(1969)\end{array}$ & $\begin{array}{l}\text { Midland Ross } \\
\text { (竪型炉方式) }\end{array}$ & 約 450 前後 \\
\hline
\end{tabular}

（出典：日本鉄銅連盟直接還元法分科会報告 $44 / 3$ その他)

\section{$4-5$ L N Gの寒冷利用}

L N G は再ガス化の際の寒冷を利用して低温プロセ スの泠媒として活用することができる。

それはL N Gが再ガス化する際 $-160^{\circ} \mathrm{C}$ から常温ま での温度にするのにL N G kg 当たり約 $200 \mathrm{kcal}$ の熱を 他から奪うことができるからである。もちろんこの寒 冷利用は温度の低い部分ほど高価で, 液酸, 液空の 製造, ウェットガスの場合のエチレン回収などは優れ た利用法であるが，この他には，MHD発電の磁極冷
却用へリウムの泠却, 液体水素の製造などが考えられ る。そしてこれらは，いずれもLNGの使用について 再ガス化能力などとの量的バランス, 立地条件を考え る必要がある。しかし再ガス化費用の間接的な低減に 結びつくことであり, 今後この分野の研究や開発㥽 極的に進める必要功ある。

\section{5.あとがき}

L N G はイオウを含まないこと，ポータブルである こと, さらに理蔵量も十分あり, エネルギ一資源とし 
て優れた性質をもつているので，大量導入してエネル ギーとして消費することは，わが国のエネルギー政策 上，その資源の多様化，産地の分散化，さらに公害対
策上からも大いに利益をもたらすことは予想できる。 しかもわが国をとりまく L N G の供給可能国の 総埋 蔵量は，表 4 から，現在でも約 8 兆 $\mathrm{m}^{\mathbf{m}}$ となり，これは

\section{表 4 わが国に対する LNG の潜在供給源（天然ガス埋蔵量）}

\begin{tabular}{|c|c|c|}
\hline 地＼cjkstart域（国） & 埋蔵量概算 $\left(10^{9} \mathrm{~m}^{3}\right)$ & 俑 考 \\
\hline アラスカ & 404.5 & $\begin{array}{l}\text { 別にノースロープでは現在でも } 8 \\
\text { 兆 } m^{3} \text { の推定埋藏量がある。 }\end{array}$ \\
\hline カ ナ ダ & $1,295.0$ & 西部諸州の埋藏量のみが効象 \\
\hline 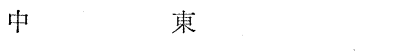 & & \\
\hline |アブダビ㧍よび中立地带 & 322.4 & 商談進行中 \\
\hline クウエート & 940.5 & \\
\hline 1 ラ ン & $2,687.0$ & \\
\hline | & 564.3 & \\
\hline パキスタン & & \\
\hline 東 & 264.6 & \\
\hline 西 & 375.0 & \\
\hline ボルネオ（ブルネイ） & 177.0 & 謪談進行中 \\
\hline インドネシア & 53.7 & $\begin{array}{l}\text { 現在は対象とならないが, 将来新 } \\
\text { 発見が期待される。 }\end{array}$ \\
\hline 大 洋 州 & & \\
\hline 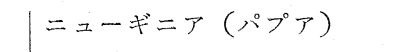 & $64\}$ & な㧍今後の新発見が期待されてい \\
\hline オーストラリア & $475\}$ & 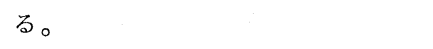 \\
\hline |ニュージーランド & 不明 & $\begin{array}{l}\text { 最近海域の新発見が伝えられてい } \\
\text { る。 }\end{array}$ \\
\hline ソ＼cjkstart連 & & \\
\hline シベリア東部（ヤクーック） & 238.6 & 1968年現在 \\
\hline サハリン & 70.1 & " \\
\hline
\end{tabular}

1985年のわが国にお抢るL N G の推定消費量を 1,000 億 $m^{3}$ とても，約80年分あることになる。これらの導 入は, 最終的には, 原油との価格対照, 資源の見通し, あるいは対公害資源としての評価によつて決められ ることであらう。しかし資源の貧しいわが国でこれを 放置しておく必要はなく, 積極的に利用するよう努力 しなければならないと思う。

それには，LNGの総合的利用体系を確立し, 大量 需要家は, それぞれのビルドアップの度合, 量, 利用 条件などを考え, コンビナート化できるなら全体的に バランスのとれた共同購入あるいは共同使用を考える べきである。また自動車燃料一の利用, 超音速旅客機 あるいは大型へリコプタ一燃料への利用が実現するこ
ろには，東京や大阪といつた限定された場所だけでな く，日本の各地に L N Gの基地ができなくてはならな い，L N Gがエネルギー資源として確固たる地位を確 立することが将来実際にできた場合は，先述したよら に1985年頃には数千万 $\mathrm{t}$ も L N Gが導入されること も可能であり,このためには新しいL N G の用途の積 極的な開発によって，その導入規模の増大をはかるべ きであろう。

\section{文献}

（1）液化天然ガス研究委員会報告一昭和 45 年 通商産業省鉱山石炭局液化天然ガス研究委員会

（2）第 2 回国際 L N G 会議報文集一-1970 


\title{
Present Status and Future Aspect of LNG
}

\author{
by Masanobu Nojiri \\ (Tokyo Gas Co., Ltd.)
}

SYNOPSIS:- LNG (Liquefied Natural Gas) has recently been footlighted in Japan as a nen non-pollution fuel. Since 1969 Tokyo Gas Company has been importing 960,000 tons of LNG per annum from Alaska for city gas production and electric power generation. Another project is contemplated to import about 4,000,000 tons of LNG per annum from Brunei. These schemes have brought on LNG age to Japan. However there are several problems which interrupt LNG from becoming a main source of energy : firstly, the higher price compared to those of competitive fuels, which could be solved by importing large quantity to acquire scale merit and also utilizing coldness and latent heat, and secondly, necessity of wide use of LNG and its technical development. The author focosses his discussion on these points. 